of which dynamic electricity presents numerous examples, and which tends to facilitate the flow of water from an electrified cloud. The agitation of the liquid, the boiling of the waters at the point where these meteors encounter the surface of the sea, are explained not only by the descending movement itself, but also by the action of the electric current, which may repel or raise liquid masses like a breeze or an impetuous wind. If we support, in

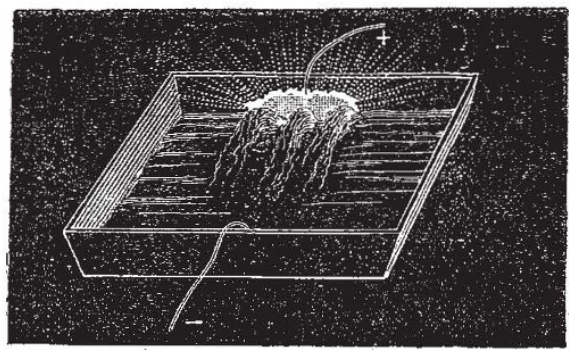

FIG. 20.-Electric bore or formation of iquid waves by the flow of a powerful current of dynamic electricity.

fact, the positive electrode against the sides of the vessel of salt-water communicating with the negative pole, we observe, besides the luminous streaks and jets abounding in vapour, a violent whirling of the liquid forming a sort of electric bore, which raises the water to the height of $\mathrm{I} \frac{1}{2}$ centimetre above its level (Fig. 19). When the current meets at certain points inequalities of resistance, it is divided and gives rise to several aqueous hillocks, as seen in Fig. 20.

\section{ON COMPASS ADFUSTMENT IN IRON SHIPS AND ON NAVIGATIONAL SOUNDINGS 1}

\section{IV.-On a Navinational Sounaing Machine.}

THE machine before you is designed for the purpose of obtaining soundings from a ship running at full speed in water of any depth not exceeding 100 or 150 fathoms. The difficulties to be overcome are twolold: first, to get the lead or sinker to the bottom; and, secondly, to get sure evidence as to the depth to which it has gone down. For practical navigation a third diffculty must also be met, and that is to bring the sinker up again; for, although in deep-sea surveys in water of more than 3,000 fathoms' depth it is advisable, even when piancforte wire is used, to leave the thirty or forty pounds' sinker at the bottom, and bring back only the wire with attached instruments, it would never do in practical navigation to throw away a sinker every time a cast is taken, and the loss of a sinker, whether with or without any portion of the line, ought to be a rare occurrence in many casts. The first and third of these difficulties seem insuperable-at all events they have not bitherto been overcomewith hemp rope for the sounding-line; except for very moderate depths, and for speeds much under the full speed of a modern fast steamer. It may indeed be said to be a practical impossibility to take a sounding in twenty fathoms from a ship running at sixteen knots with the best and best-managed ordinary deepsea lead. Taking advantage of the great strength and the small and smooth area for resistance to motion through the water, presented by pianoforte wire, I have succeeded in overcoming all these difficulties; and with such a sounding machine as that before you the White Star liner Britannic (Messrs, Ismay, Imrie, and Co., Liverpool) now takes soundings regularly, running at sixteen knots over the Banks of Newfoundland and in the English and Irish Channels in depths sometimes as much as 130 fathoms. In this ship, perhaps the fastest ocean-going steamer in existence, the sounding machine was car efully tried for several voyages in the hands of Capt. Thompson, who succeeded per. fectly in using it to advantage; and under him it was finally introduced into the service of the White Star Line.

1 Report of paper read to the Royal United Service Institution, February 4, by sir Wm. Thomson, LL.D., F.R.S., P.R.S.E., Professor of Natural Philosophy in the University of Glasgow, and Fellow of St. Peter's College, Cambrilge. kevised by the Author. [The Council of the R.U.S.I. have s to publish Sir W. Thomson's paper in advance, and haye granted us the use of the illustrations. -ED.] Contiuued from p. 354.
The steel wire which I use weighs nearly $I_{\frac{1}{2}}$ lbs. per 100 fathoms, and bears when fresh, from 230 to $240 \mathrm{lbs}$. without breaking ; its circumference is only $\mathrm{O} 3$ of an inch. By carefully keeping it always, when out of use, under lime water in the galvanised iron tank prepared for the purpose, which you see before you, it is preserved quite free from rust, and, accidents excepted, this sounding line might outlive the iron plates and frames of the ship. If the sinker gets jammed in a cleft of rock at the bottom, or against the side of a boulder, the wire is inevitably lost. Such an accident must obviously be very rare indeed, and there does not seem to be any other kind of accident which is altogether inevitable by care in the use of the instrument. The main care in respect to avoidance of breakage of the wire may be stated in three words-beware of kinks. A certain amount of what I may call internal molecular wear and tear will probably occur through the wire bending round the iron guard rod which you see in the after part of the instrument, when, in hauling in, the wire does not lead fair aft in the plane of the wheel, as is often the case even with very careful steering of the ship, but from all we know of the elastic properties of metals, it seems that thousands of casts might be taken with the same wire before it would be sensibly weakened by internal molecular friction. Practice has altogether confirmed these theoretical anticipations so far as one year of experience can go. My sounding machine has been in regular use in charge of Captains Munro and Hedderwick in the Anchor liners Anchoria and Devonia (Messrs. Henderson Brothers, Glasgow) for eleven months and seven months respectively, and in neither ship has a fathom o wire been lost hitherto, though soundings have been taken at all hours of day and night, at full speed, in depths sometimes as great as I20 fathoms. No break not explicable by a kink in the wire has hitherto taken place in any ship provided with the sounding machine. That it will bear much rough usage is well illustrated by one incident which happened in a cast taken from the Devonia running at thirteen knots. The sinker in falling from the wheel into the water accidentally fell between the rudder chain and the ship, and fifty fatboms or so had gone out before it was noticed that the wire was running down vertically from the wheel instead of nearly horizontally as it ought to have been by that time. The handles were immediately applied to the sounding wheel, and it was turned round to haul in without reducing the speed of the ship. Though the wire was bent almost at right angles round the chain until it was nearly all in, it was all got safely on board, as was also the cod-line with attached depth gauge, and the sinker at the end of it.

When soundings are being taken every hour or more frequently (as in the case of a ship feeling her way up channel from the 100 fathom line when the position is not known with sufficient certainty by sights and chronometers) the sounding wheel should be kept on its bearings in position; with the cod-line, depth gauge, and sinker, all bent on and ready for use. But in all other cases the wheel should be kept in its tank under lime water, and the cod-line with sinker and depth gauge attached should be kept at hand in a convenient place near the stand of the machine, which should be always fixed in position ready for use. With such arrangements, and methodical practice, as part of regular naval drill in the use of the sounding machine, one minute of time should suffice to take the sounding wheel out of its tank, place it on its bearings, adjust the brake cord, bend on the cod-line, and be quite ready for a cast. When the machine is to be shown to an inspecting officer the wheel ought to be in its tank of lime water when he asks to see a cast. It should be carefully noticed that the ring at the end of the wire is securely lashed by small cord to the hole provided for it in the ring of the wheel whenever the cod-line is unbent from the ring. If the wire and ring are allowed at any time to knock about slack on the wheel when the wheel is being moved to be set up for use or to be replaced under the lime-water there is a liability to some part of the wire getting a turn which may be pulled into a kink. One accident, at least, has happened in this way: the sinker dropped off carrying the cod-line and ring with it just as it was being let down trom the taffrail for a cast. If the sinker had weighed $400 \mathrm{lbs}^{1}{ }^{1}$ it could not have broken the double wire next the ring without a kink.

A description of the machine and rules for its use are given in the accompanying printed paper of instructions, to which I have only now to add a few words regarding the depth gauge. Erichsen's self-registering sounding lead (patented in 1836), depending on the compression of air, might be used with my machine, but the simpler form before you is preferable as beingr It weighs $22 \mathrm{lbs}$. 
surer. It too depends on the compression of air, but in it the extent to which the air has been compressed is marked directly on the interior of a straight glass tube by the chemical action of sea-water on a preparation of chromate of silver with which the tube is lined internally. Between the salt of the sea-water and the chromate of silver a double decomposition takes place. The chlorine leaves the sodium of the common salt and combines with the silver, while the chromic acid and oxygen leave the silver and combine with the sodium. Thus chloride of silver, white and insoluble, remains on the glass in place of the orangecoloured chromate of silver lining as far up as the water has been forced into the tube, and the chromate of sodium dissolved in the water is expelled as the air expands when the tube is brought to the surface.

My mavigational spunding machine was brought into practical use for the first time in the steamship Palm, belonging to Messrs. Charles Horsfall and Co., Liverpool, in a voyage to Odessa and back about a year ago, in command of Capt. E. Leighton. I cannot illustrate the use of the machine better than by reading to you an extract from a letter I received last April from Capt. Leighton, describing his experience of it in this first trial :-

"During the voyage in the Palm steamship, which has just come to an end, I took frequent opportunities of testing the sounding machine when I had a chance of cross-bearings to verify the depths as shown by chart, and always found it most accurate. For instance, going up through the Archipelago and just after clearing the Zea Channel, I got a good position by bearings, chart showing seventy-nine and seventy-six fathoms, two casts of your glass gave seventy-eight and seventy-five fathoms. In the Bosphorus also it gave capital results in thirty to forty fathons water.

" "The first real use I made of the machine was in the Black Sea during a fog which obscured everything. Wishing to make sure of my position I put the ship's head for the land and kept the machine at work. After running in to thirty fathoms at full speed I slowed down and went in to twelve fathoms, then hauled, out to a convenient depth and put her on the course up the coast. When it became clear I found myself in a proper position, and no time had been lost by stopping to sound.

" How many shipmasters let hours go by without obtaining soundings either because of the delay or on account of the danger of rounding-to in heavy. weather to get them, when, if they were provided with your sounding-machine, they could have their minds set at ease by having timely warning of danger, or by knowing that they were in a good position!"

I had myself very satisfactory experience of the usefulness of the sounding machine in coming up Channel running before a gale of south-west wind in thick weather, on the 6th and 7 th of last August, on returning from Nacieira in my yacht-a small sailing schooner of 126 tons. About 5 A.M. on the 6th I took two casts and found ninety-eight fathoms (sand and red spots) and $10 \mathrm{I}$ fathoms (sand and small shells). The mean with a correction of $2 \frac{1}{2}$ fathoms to reduce to low water, according to the state of the tide at Usbant at the time, was ninety-seven fathoms. Thenceforward I took a sounding every hour but one till eight in the evening. By writing these soundings on the edge of a piece of paper at distances equal according to the scale of the chart to the distances run in the intervals, with the edge of the paper always parallel to the course, according to the method of Sir James Anderson and Capt. Moriarty, $X$ had fixed accurately the line along which the vessel had sailed, and the point of it which had been reached, with only a verification by a noon latitude. At 6 o'clock next morning, by the soundings and course, with proper allowance for the flood-tide, I must have been about thirteen miles magnetic south of the Start, but nothing of the land was to be seen through the haze and rain; and with the assistance of about ten more casts of the lead (by which I was saved from passing south of St. Catherine's) I made the Needles Lighthouse right ahtad, at a distance of about three miles, at 2 P.M., having had just a glimpse of the high cliffs east of Portland, but no other sight of land since leaving Madeira and Porto Santo. In the course of the 280 miles from the point where I struck the roo fathom line to the Needles, I took about thirty casts in depths of roo fathoms to nineteen fathoms without once rounding-to or reducing speed; during some of the casts the speed was ten knots, and the average rate of the last 220 miles was a little over nine knots.

It is a pleasure to me to be able to add that the sounding machine has also been successfully used in the Royal Navy,
Admiral Beauchamp Seymour and Capt. Lord Walter Kerr having kindly taken it on board H.M.S. Mino'aur for trial last summer. Lord Walter Kerr wrote, on his return from Vigo, regarding it as follows :-

"The sounding machine is most serviceable. We have been using it constantly when running up Channel, from the time of crossing the line of soundings to the time of reaching Plymouth, and though running before a gale of wind with a heavy sea, at the rate of ten knots, we were able to get soundings as if the ship had been at anchor. We were able to signal to the squadron each sounding as it was obtained; thus, in thick weather, verifying our position by soundings without having to round the ships to."

\section{THE ANALOGIES OF PLANT AND ANIMAL LIFE} ET us begin our inquiry into the analogies of plant and
animal life by comparing the egg of an animal with the seed of a plant. Let it be the ripe seed of a common plant, and the egg of a bird. Both seed and egg may be said to consist of the young creature and a supply of food which is stored up for its use, and is gradually exhausted as the young creature develops. Every one who has tried when a boy to blow a late bird's egg must have been painfully alive to the fact of its containing a young animal, and the egg we eat for breakfast may serve to remind us of the store of food which we diverted from its proper course of nourishing a young chicken.

Here is a diagram representing a section through the seed of a poppy, in which the young plant may be seen lying in its store of food containing a supply of carbohydrates and nitrogenous matter, which is consumed as the yolk of the egg is consumed by the young chicken. Other seeds, such as a bean, an acorn, or ar almond, seem at first sight to consist of nothing but the young plant, and to have no store of food. The two halves into which a pea split are the two first leaves or cotyledons of the yourig plant, the emoryo stem and root being represented by the little projecting mass lying between the two halves at one end of the seed. Here the store of food is laid up in the body of the young plant just as many young animals carry with them a store of food in the shape of the masses of fat with which they are cushioned; the two leaves which seem so gigantic compared with the rest of the plant are filled with nutriment, and perform the same function of supplying food for the growth of the seedling, which is performed by the mass of nutrient material in which the entbryo of the poppy seed is embedded. Recent researches have shown that embryo plants are possessed of powers which even in the present day it seems almost ludicrous to ascribe to them. I mean powers of digestion. GorupBesanez, 2 a distinmuished German chemist, found that in the germinating seed of a vetch a ferment exists similar to the ferment in the pancreatic secretion of animals-a secretion having the power of relucing both nitrogenous bodies and starch to a condition in which they can be utilised and absorbed by the tissues, so that the embryo plant behaves exactly as if it were a minute animal digesting and absorbing the store of food with which it is supplied. The power of digesting starch possessed by the embryo plant has been brilliantly demonstrated by van Tieghem, ${ }^{3}$ who found that the embryo removed from the sced of the Marvel of Peru (Mirabilis jalapa) was distinctly nourished if placed in an artificial seed made of starch paste. He found that the starch paste was actually corroded by the young plant, proving that a digestive ferment had been at work.

This wonderful experiment is of special interest as proving that the digestive ferment is a product of the young plant itself, just as the digestive juice of an animal is a secretion from its stomach. It is indeed a striking thought that whether we grind up a grain of wheat to flour and eat it ourselves as bread, or whether we let the seed germinate, in which case the young plant eats it, the process is identically the same.

The power of storing up food in a fixed condition and utilising it when required is a most imporfant function both in animal and plant physiology. And just as this utilisation is seen in the seed to be brought about by a fermentby a digestive process--so probably wherever the transference or utilisation of food stores occurs it is effected by ferments. If this be so it would seem that the processes of

${ }^{x}$ A Lecture delivered at the London Institution on March $x$ by Francis Darwin, M.B.

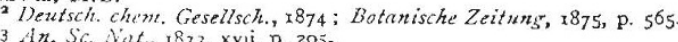
3 An. Sc. Natt., 1873 , xvi. p. 205 . 